\title{
Follicle and stroma integrity after holding ovarian tissue for up to 8 hours before vitrification in a metal closed system
}

\author{
Integridade folicular e do estroma após manutenção do tecido ovariano \\ por até 8 horas antes da vitrificação em um sistema metálico fechado
}

\author{
L.S. Marques ${ }^{1}$, J.L. Rodrigues ${ }^{1}$, N. Lothhammer, N2 Frantz $^{3}$, A. Bos-Mikich ${ }^{2}$ \\ ${ }^{1}$ Reproduction Biotechnologies Laboratory, Veterinay School, Federal University of Rio Grande do Sul, \\ Porto Alegre, RS, Brazil \\ 2 Department of Morphological Sciences, ICBS, Federal University of Rio Grande do Sul, Porto Alegre, RS, Brazil \\ ${ }^{3}$ Nilo Frantz Research and Human Reproduction Center, Porto Alegre, RS, Brazil. \\ Accredited Redlatra Center
}

Local de Realização: Departamento de Ciências Morfológicas/ICBS/UFRGS e Laboratório de Biotecnologias da Reprodução/Faculdade de Veterinária/UFRGS.

\begin{abstract}
Objectives: ${ }^{1}$ Assess the effects of a prolonged period of incubation ( $8 \mathrm{hrs}$ ) prior to vitrification, on ovarian follicle and stroma morphology; ${ }^{2}$ Test the effect of low maintenance temperature before ovaries are cryopreservaed; ${ }^{3}$ Certify the effectiveness of an aluminium caddy for vitrification of ovarian tissue in terms of primordial and primary follicular morphology and stromal elements after rewarming. Methods: Whole mouse ovaries were left for 8 hrs prior to cryopreservation in HTF medium at $4^{\circ}$.C or room temperature (RT), vitrified inside an aluminium caddy, that was placed into a tightly closed plastic cryovial and then plunged into liquid nitrogen (LNi). Controls were fixed soon after collection. Control and rewarmed ovarian fragments were processed for histology. Slides were analyzed blindly.

Results: Primordial follicles presented a superior recovery rate $(78 \%)$ compared with primary follicles $(27 \%)$, after being maintained at RT for 8 hrs before vitrification. No significant difference was observed between vitrified and control primordial follicles. When ovaries were maintained at $4^{\circ} . C$, primordial and primary follicle norma morphology rates were $58 \%$ and $21 \%$, respectively..

Conclusions: Considering that primordial follicles represent the ovarian reserve, these results allow us to suggest that the maintenance of ovarian tissue at RT for up to 8 hours prior to vitrification is a more appropriate procedure for transport or storage than keeping the specimens at 4o.C. In addition, the metal container is an ideal tool for clinical grade ovarian tissue cryopreservation, in fertility preservation programs.
\end{abstract}

Key-words: vitrification, ovarian tissue, time and temperature of transport, metal vessel

\section{RESUMO}

Objetivos: ${ }^{1}$ Avaliar efeitos de um período de incubação prolongado ( 8 horas) antes da vitrificação, sobre a morfologia dos folículos ovarianos e estroma; ${ }^{2}$ acessar conseqüências da baixa temperatura de manutenção dos ovários antes da criopreservação sobre a morfologia folicular e do estroma ${ }^{3}$ confirmar eficácia da vitrificação de tecido ovariano em um recipiente metálico, em termos de morfologia dos folículos primários e primordiais e do estroma, após aquecimento.

Métodos: Ovários murinos inteiros foram mantidos por
8 horas antes da criopreservação em meio HTF a $4^{\circ}$. C ou temperatura ambiente (TA), vitrificados em um receptáculo metálico, o qual foi inserido dentro de um criotubo plástico hermeticamente fechado e imerso no nitrogênio liquido (LNi). Controles foram fixados logo após a coleta. Ovários controle e reaquecidos foram processados para histologia. Lâminas foram analisadas às cegas.

Resultados: Folículos primordiais apresentaram uma taxa superior de recuperação (78\%) em comparação com os primários (27\%), após 8 hrs de manutenção a TA antes da vitrificação. Não houve diferença significativa entre folículos primordiais controles e vitrificados. Ovários mantidos a 40.C, apresentaram taxas de morfologia normal de folículos primordiais e primários de $58 \%$ e $21 \%$, respectivamente.

Conclusões: Considerando-se que os folículos primordiais representam a reserva ovariana, nossos dados sugerem que a manutenção do tecido ovariano por até 8 horas a TA antes da criopreservação é o procedimento mais adequado para transporte ou armazenamento do material biológico sendo o recipiente metálico um veículo adequado para vitrificação com grau clínico em programas de preservação da fertilidade feminina.

Palavras-chave: vitrificação, tecido ovariano, tempo e temperatura de transporte, recipiente metálico

\section{INTRODUCTION}

Cryopreservation of ovarian tissue is an attractive option to restore ovarian function and fertility in women facing an oncological treatment. Although ovarian tissue cryopreservation may not yet be considered an established procedure in clinical practice, there are encouraging reports of restored ovarian function (Rosendhal et al., 2011; Silber et al., 2012), induction of puberty (Poirot et al., 2012) and several babies have been born after autografting (Andersen et al., 2008; Donnez et al., 2012; Muller et al., 2012).

Different studies have shown that vitrification is possibly the best choice of cryopreservation method of ovarian tissue for different species, including humans and rodents (Sugimoto et al., 2000; Tokieda et al., 2002; Migishima et al., 2003; Almodin et al., 2004a; Almodin et al., 2004b; Chen et al., 2006; Isachenko et al., 2009; Keros et al, 2009; Rosendhal et al., 2011; Sheiki et al., 2011). However, there are two important points to appraise when vitrification is to be performed for human clinical grade ovarian tissue cryo-banking. First, there is the need of very fast cooling rates to diminish the toxici- 
ty effect of relatively high concentrations of cryoprotectants, before vitrification takes place. Second, there is the putative risk of contamination of the biological material by pathogens present in the liquid nitrogen (LNi), which may pass to the tissue, embryo or gamet during cryostorage (Bielanski et al., 2000).

Considering these two key factors for a successful vitrification and subsequent tissue survival free of pathogens, we developed a protocol that employs a small metal caddy for vitrification, which is subsequently tightly enclosed into a plastic cryovial, so that the ovarian tissue never enters in direct contact with the LNi (Bos-Mikich et al., 2012). In that previous study, we have shown good rates of primordial ( 81 $\%)$ and primary (27\%) follicles survival after vitrification under this system, when the ovaries were maintained up to four hours at RT before cryopreservation. Those results prompted us to investigate a longer pre-vitrification time, at $\mathrm{RT}$ and at $4 \mathrm{oC}$, considering that in several clinical situations, the site of tissue collection may not have cryopreservation or cryo-storage facilities or even skilled staff to perform the procedure. In this scenario the ovarian sample may have to travel to another Institution to be prepared for cryopreservation and stored, which may take hours en route.

\section{MATERIAL AND METHODS}

\section{Animals}

Female Albino mice were maintained under controlled lightening (12L:12D), temperature (20 to $25^{\circ} \mathrm{C}$ ) and humidity $(40-60 \%)$ conditions in a the Animal Facility of our University. The study was approved by our Institutional Ethics Committee.

\section{Vitrification}

Whole ovaries were dissected from six, 2-3 week-old albino female mice. Each experimental group was composed of three ovaries from different females. One ovary of each of the six females was placed in TC199 (Sigma-Aldrish, USA) medium supplemented with $20 \%$ fetal calf serum (FCS; Nutricel, Campinas, SP) for eight hours in one the following experimental groups: 1 ) at $4^{\circ} \mathrm{C}$ on ice or 2) at R.T. $\left(23-25^{\circ} \mathrm{C}\right)$. The other ovary of each of the same six females was fixed immediately after collection in Bouin's solution as control.

Cryopreservation protocol followed a modification of the method described by Choi et al.(2007) for the vitrification of mice ovaries. Ovaries were carefully removed from the collection medium and exposed first to an equilibrium solution (ES) of TCM199 containing $20 \%$ (v:v) FCS, $7.5 \%$ ( $v: v)$, ethylene glycol (EG) and $7.5 \%$ (v:v) dimethyl sulfoxide (DMSO) for $15 \mathrm{~min}$ at R.T. followed by exposure to the vitrification solution (VS) containing $15 \%$ (v:v) EG, $15 \%$ (v:v) DMSO and 0.5 M sucrose. From VS, the ovaries were gently transferred with a minimum volume of medium to a handmade aluminum foil caddy, within $90 \mathrm{~s}$ of exposure to VS and the loose ends of the caddy were closed with a pair of forceps. The bottom side of this little caddy was placed in contact with the surface of the LNi,. At the same time an $1.8 \mathrm{ml}$ Nunc cryotube was immersed in the LNi with its open end above the surface to avoid LNi coming inside the tube. The closed caddy was placed into the cryotube, which was then tightly closed, plunged into LNi and stored for a period between 2 days and 4 weeks before warming.

\section{Warming and histological analysis}

To rewarm, the cryotubes were taken from the LNi, the lids removed and the aluminium caddy was exposed to R.T. for 30-40 s followed by water bath at 37o.C till the medium surrounding the ovary has melted. After careful removal from the aluminum container, the ovaries went through two 5 min steps in warming solutions consisting of TCM199 medium and $20 \%$ FCS, supplemented with 1 $\mathrm{M}$ and $0.5 \mathrm{M}$ sucrose, respectively, at R.T. Subsequently, ovaries were fixed in Bouin's solution for $2 \mathrm{~h}$. The fixative was replaced with $70 \%$ alcohol and processed for histological analysis. Ovaries were serially sectioned at 5 $\mu \mathrm{m}$ thickness. The sections were mounted on glass slides and stained with hematoxylin and eosin (HE). Every forth section of each ovary was analyzed for primordial and primary follicular morphology and stroma integrity. Only follicles with a visible nucleus in the oocyte were considered for counting to avoid counting twice the same oocyte and follicle. We considered primordial follicles as those surrounded by one flat layer of follicular cells and primary follicles as those surrounded by one layer of cuboidal follicular cells. We did not analyze growing or secondary, antral follicles. We considered intact follicles the ones that did not present any contraction of the oocyte cytoplasm or picnotic nuclei. The follicular cells should not be detached from the basement membrane and there should not be any enlarged space between them. Analyses were performed at final magnification of 400X using an Olympus BX41 light microscope. Slides underwent blind analysis, by one experienced embryologist.

\section{Statistical analysis.}

Differences between groups were analyzed using $X^{2}$. A value of $P<0.05$ was considered statistically significant.

\section{RESULTS}

The total numbers and percentages of morphologically normal, primordial and primary follicles in vitrified and control ovaries submitted to the different temperatures before cryopresevation are presented in Table I.

Representative pictures of follicular morphology and stroma are shown in Figures 1 and 2 .

Primordial follicles from ovaries that were exposed to RT did not present significant changes $(P=0.2694)$, when compared with controls. However, ovaries exposed to 4 ${ }^{\circ} \mathrm{C}$ for $8 \mathrm{~h}$ before vitrification showed a significantly lower percentage of normal primordial follicles $(P=0,0001)$. On the other hand, primary follicles presented a pronounced decrease in normal morphology in both experimental groups $(P=0.0001), R T$ and $40 . C$, when compared with

Tabela 1. Total numbers and percentage of primordial and primary follicles presenting normal morphology, after $8 \mathrm{~h}$ at two different temperatures prior to vitrification and controls.

\begin{tabular}{lcccc}
\hline Groups & \multicolumn{2}{c}{$\begin{array}{c}\text { Primordial } \\
\text { Follicle }\end{array}$} & Primary Follicle \\
\hline & $\mathrm{N}$ & $(\%)$ & $\mathrm{N}$ & $(\%)$ \\
\hline Room Temperature & $223 / 285^{\mathrm{a}}$ & 78 & $124 / 459^{\mathrm{a}}$ & 27 \\
\hline Temperature of $4^{\circ} \mathrm{C}$ & $208 / 358^{\mathrm{b}}$ & 58 & $116 / 558^{\mathrm{b}}$ & 21 \\
\hline Controls & $53 / 62^{\mathrm{a}}$ & 85 & $100 / 129^{\mathrm{c}}$ & 78 \\
\hline
\end{tabular}

Different subscripts within a column indicate significant differences among groups.

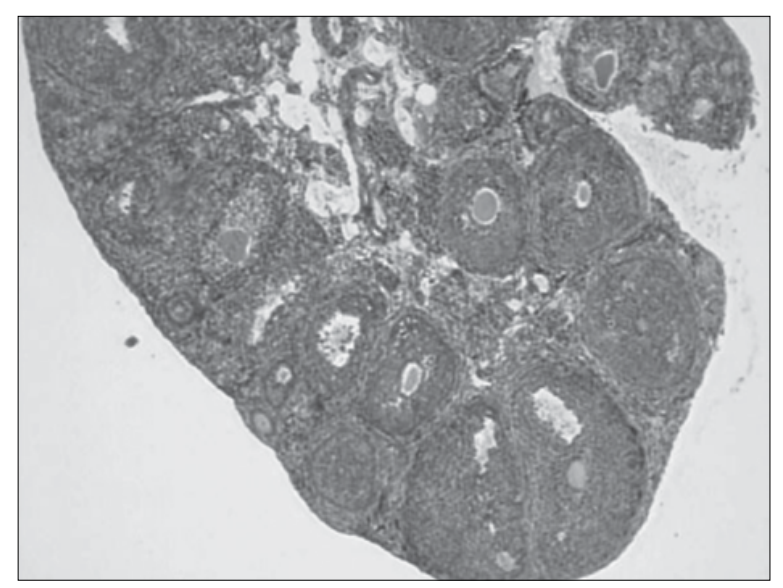

Figure 1. Light microscopy panoramic view of a whole ovary showing follicles at different growth phase and non-disrupted well, organized stroma after vitrification. 


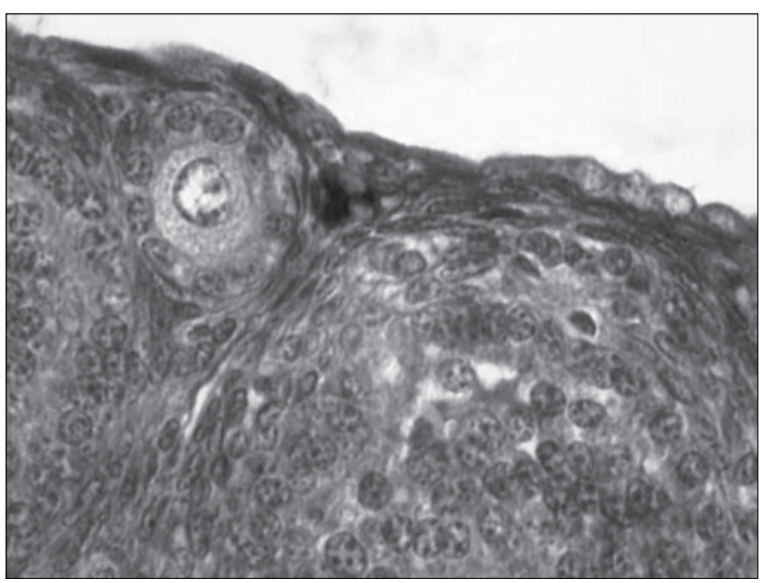

Figure 2. Higher magnification of a primary follicle and stromal elements of mouse ovarian cortex after vitrification in an aluminium caddy. Note the perfect integrity of the follicular cells and the perfect basal membrane surrounding the follicles (black arrow head).

controls. Again, the poorer results in terms of normal follicular morphology were observed when ovaries were exposed for $8 \mathrm{~h}$ to $4^{\circ} \mathrm{C}$. These observations suggest that primary follicles are more sensitive to cryodamage, than primordial follicles.

Important to point out in Figure 1 is the remarkable integrity of the ovarian stromal elements: collagen fibers and cells look as normal as controls, without any signs of necrosis or empty areas. Overall, our data suggest that ovarian tissue can be maintained for up to $8 \mathrm{hr}$, before vitrification and the aluminium foil caddy is an appropriate tool to vitrify ovarian tissue under clinical grade conditions. Also, R.T is a more appropriate temperature to maintain and transport ovaries, than $4{ }^{\circ} \mathrm{C}$ to best preserve primary and primordial follicles and the stroma components for up to $8 \mathrm{~h}$ before cryopreservation.

\section{DISCUSSION}

The present results confirm and extend our previous observations (Bos-Mikich, 2012) that mouse ovaries can successfully be vitrified using a metal container that goes inside a plastic cryovial, ensuring a fast cooling rate and avoiding the risk of contamination during vitrification and storage. Most relevant, we show that the normal morphology of primordial follicles do not undergo any significant change after ovarian exposure at R.T. for up to $8 \mathrm{~h}$, prior to vitrification in the aluminium foil caddy. Primordial follicles presented a very good recovery rate in terms of normal morphology and they represent the ovarian reserve or the fertility potential of a female. Thus, their integrity after cryostorage is paramount in fertility preservation procedures for women facing a cancer treatment or any other condition that may affect their ovarian reserve. Previous reports have already demonstrated high rates of primordial follicle survival after different cryopreservation protocols (Jeremias et al., 2003; Donnez et al., 2012). In addition, another study showed that morphology and markers of early follicle growth of primate primordial follicles are well preserved after slow freezing and thawing (Jin et al., 2010).

Our present results confirm that primary follicles are more sensitive to cryopreservation in comparison with the primordial ones, as they presented a higher rate of damage after maintenance at different times and temperatures prior to vitrification using the metal container (Bos-Mikich et al., 2012). Possibly, disruption of the physical connections present between the follicular cells forming the single layer surrounding the oocyte in primary follicles, due to cryopreservation leads to an irreversible damage to their organization. It is known that the development of primary follicles leads to a significant increase in the number of gap junctions between follicular cells, as well as between them and the oocyte (Johnson et al., 1999). Gap junctions are formed by well-organized proteins that form a channel between two adjacent cells to provide essential pathways for communication between them. On the other hand, primordial follicles are smaller structures and the physical connections between the oocyte and surrounding squamous granulosa cells are loose and connections between them and the oocyte are not yet established. One previous study that compared the morphology of primordial and primary follicles in fresh and cryopreserved ovarian tissue (Ting et al., 2011) did not find any difference between the two groups. However, the authors did not present any statistical analysis of their findings and based their conclusions in morphological observations and photographs. We believe that our results clearly show that primordial follicles are more resilient to cryodamage, than primary ones. In addition, the vitrification system here described seems to guarantee a perfect integrity of the ovarian stromal elements, fibroblasts and other cells, which did not show any signs of degeneration such as picnotic or shrunk nuclei. The extracellular matrix fibrous components such as the collagen fibers showed no gaps or empty areas among follicles. These observations represent a key factor when tissue transplantation is considered, because the stromal elements are responsible for tissue survival through the production of angiogenic factors and consequently the generation of new blood vessels. Also, an appropriate blood supply is paramount for follicular viability and growth for the re-establishment of ovarian function. Our results show a normal stroma surrounding primordial and primary follicles after vitrification in the aluminium caddy system.

Another point to mention is the fact that the poorer results in terms of follicular morphology, both for primordial and primary follicles, were observed when the ovaries were placed in ice at $4{ }^{\circ} \mathrm{C}$, prior to cryopreservation. This observation has been previously discussed by us (Bos-Mikich et al., 2012) and it may represent an unexpected finding considering that in human organ transplantation practice, the specimens are transported in a hypothermic state sometimes for hours for best organ preservation and survival until it is time to be transplanted. Specifically for ovarian tissue, we did not find any controlled study showing the best maintenance temperature between collection and cryopreservation or manipulation. In humans, one publication describes the transport of ovarian tissue from the collection site to the laboratory in flushing medium at $4{ }^{\circ} \mathrm{C}$ (Sheiki et al., 2011), while another study used medium at R.T. for the transport of the ovarian fragments (Keros et al., 2009). In both studies, cryopreservation started within 5 min after collection, in the same Institution, a situation which may not be possible in several clinical situations, when the time and temperature of transport may play a key role on the survival of the cryopreserved tissue. Thus, it seems that there isn ' $t$ a consensus on best maintenance temperature specifically for ovarian tissue transport prior to laboratory procedures and our results shed a light on this question showing that 40.C may not be the most adequate temperature for specimens viability, even when cryopreservation is not being considered.

We did not test in vitro or in vivo viability of the warmed tissue samples, however, we believe that the morphology assessment is a good marker of cell and follicular viability similar to reports presented in previous studies (Jeremias et al., 2003; Chen et al., 2006; Jin et al., 2010). The final proof of ovarian tissue and follicle viability after cryopreservation using the metal vessel and closed system for vitrification, would be to produce healthy puppies, and subsequently, human babies. In conclusion, results here presented using a metal vessel for vitrification suggest that ovarian tissue may be maintained at RT for up to $8 \mathrm{~h}$. before cryopreservation without losing follicular viability, specially the primordial follicle pool that represents the reproductive potential of a woman. In human medicine, the metal 
container for vitrification shall potentially be employed as a clinical grade device for cryopreservation of ovarian tissue fragments, as it is not cytotoxic and the tissue does not have any direct contact with the LNi.

\section{Corresponding author}

Adriana Bos-Mikich

Departamento de Ciências Morfológicas

Instituto de Ciências Básicas da Saúde

Universidade Federal do Rio Grande do Sul

Av. Sarmento Leite 500

Porto Alegre, RS

CEP: $90.050-170$

adriana.bosmikich@gmail.com

\section{REFERENCES}

Almodin CG, Minguetti-Câmara VC, Meister $H$, Ferreira JO, Franco RL, Cavalcante AA, Radaelli MR, Bahls AS, Moron AF, Murta CG. Recovery of fertility after grafting of cryopreserved germinative tissue in female rabbits following radiotherapy. Hum Reprod 2004; 19:1287-93.

Almodin CG, Minguetti-Camara VC, Meister $H$, Ceschin $A P$, Kriger E, Ferreira JO. Recovery of natural fertility after grafting of cryopreserved germinative tissue in ewes subjected to radiotherapy. Fertil Steril 2004; 81:160-4.

Andersen $C Y$, Rosendahl M, Byskov AG, Loft A, Ottosen C Dueholm M, Schmidt KL, Andersen AN, Ernst E. Two successful pregnancies following autotransplantation of frozen/thawed ovarian tissue. Hum Reprod 2008;23:2266-2272.

Bos-Mikich Adriana Bos-Mikich, Lis Marques, José Luiz Rodrigues, Nívia Lothhammer, Nilo Frantz. The use of a metal container for vitrification of mouse ovaries, as a clinical grade model for human ovarian tissue cryopreservation, after different times and temperatures of transport. J Assist Reprod Genet (2012) 29:1267-1271.

Chen SU, Chien CL, Wu MY, Chen TH, Lai SM, Lin CW Novvel direct cover vitrification for cryopreservation of ovarian tissues increases follicle viability and pregnancy capability in mice. Hum Reprod 2006; 21:2794-800

Choi JY, Lee J-Y, Lee EY, Yoon B-K, Boe DS, Choi DS. Cryopreservation of the mouse ovary inhibits the onset of primordial follicle development. Cryobiology 2007;54:55-62.

Donnez J, Jadoul P, Pirard C, Hutchings G, Demylle D, Squifflet J, Smitz J, Dolmans MM. Live birth after transplantation of frozen-thawed ovarian tissue after bilateral oophorectomy for benign disease. Fertil Steril 2012; 98:720-5.

Isachenko $V$, Lapidus $I$, Isachenko $E$, Krivokharchenko A, Kreienberg R, Woriedh M, Bader M, Weiss JM. Human ovarian tissue vitrification versus conventional freezing: morphological, endocrinological, and molecular biological evaluation. Reproduction 2009; 138:319-27.

Jeremias E, Bedaiwy MA, Nelson D, Biscotti CV, Falcone T. Assessment of tissue injury in cryopreserved ovarian tissue. Fertil Steril 2003;79:651-3.
Jin SY, Lei L, Shea LD, Zelinski MB, Stouffer RL, Woodruff TK. Markers of growth and development in primate primordial follicles are preserved after slow cryopreservation. Fertil Steril 2010;93:2627-32

Johnson ML, Redner DA, Reynolds LP, Grazul-Bilska AT. Expression of gap junctional proteins connexin 43, 32 and 26 throughout follicular development and atresia in cows. Endocrine 1999; 10: 43-51.

Keros V, Xella S, Hultenby K, Pettersson K, Sheikhi M, Volpe A, Hreinsson J, Hovatta O. Vitrification versus controlledrate freezing in cryopreservation of human ovarian tissue. Hum Reprod 2009; 24:1670-83.

Migishima F, Suzuki-Migishima R, Song SY, Kuramochi T, Azuma S, Nishijimi M. Successful cryopreservation of mouse ovaries by vitrification. Biol Reprod 2003; 68:881-7

Müller A, Keller K, Wacker J, Dittrich R, Keck G, Montag $M$, Van der Ven $H$, Wachter $D$, Beckmann MW, Distler W. Retransplantation of cryopreserved ovarian tissue: the first live birth in Germany. Dtsch Arztebl Int 2012; 109:8-13.

Poirot C, Abirached F, Prades M, Coussieu C, Bernaudin F, Piver $P$. Induction of puberty by autograph of cryopreserved ovarian tissue. Lancet. 2012; 6736: 61781-9.

Rosendhal M, Schmidt KT, Ernst E, Rasmussen PE, Loft A, Byskov AG, Andersen AN, Andersen CY. Cryopresevation of ovarian tissue for a decade in denamark: a view of the technique. Reprod Biomed Online 2011; 22:162-71.

Santos RR, Amorim C, Cecconi S, Fassbender M, Imhof M, Lornage J, Paris M, Schoenfeldt V, Martinez-Madrid B. Cryopreservation of ovarian tissue: an emerging technology for female germline preservation of endangered species and breeds. Animal Reproduction Science 2010; 122:151-63.

Sheikhi M, Hultenby K, Niklasson B, Lundqvist M, Hovatta $O$. Clinical grade vitrification of human ovarian tissue: an ultrastructural analysis of follicles and stroma in vitrified tissue. Hum Reprod 2011;26:594-603

Silber SJ. Ovary cryopreservation and transplantation for fertility preservation. Mol Hum Reprod 2012; 18:59-67.

Sugimoto M, Maeda S, Manabe N, Miyamoto H. Development of infantile rat ovaries autotransplanted after cryopreservation by vitrification. Theriogeneology 2000;53:1093-103

Ting AY, Yeoman RR, Lawson MS, Zelinski MB. In vitro development of secondary follicles from cryopreserved rhesus macaque ovarian tissue after slow-rate freeze or vitrification. Hum Reprod 2011;26:2461-72.

Tokieda Y, Ishiwata I, Segino M, Ishikawa H, Sato K. Establishment of a novel method for cryopreservation and thawing of the mouse ovary. Hum Cell 2002;15:230-7.

Wiedemann C, Zahmel J, Jewgenow K. Short-term culture of ovarian cortex pieces to assess the cryopreservation outcome in wild felids for genome conservation. BMC Vet Res 2013; 22; 9: 37. doi:10.1186/1746-6148-9-37 